\title{
Information about Human Evolution: An Analysis of News Published in Communication Media in Spanish between 2015 and 2017
}

\author{
Jon Ander Garibi, Alvaro Antón (D) and José Domingo Villarroel *D \\ Faculty of Education Bilbao, University of the Basque Country (UPV/EHU), 48940 Leioa, Spain; \\ jonander.garibi@ehu.eus (J.A.G.); alvaro.anton@ehu.eus (A.A.) \\ * Correspondence: txomin.villarroel@ehu.eus; Tel.: +34-94-601-75-21
}

Citation: Garibi, J.A.; Antón, A.; Villarroel, J.D. Information about Human Evolution: An Analysis of News Published in Communication Media in Spanish between 2015 and 2017. Publications 2021, 9, 28. https:// doi.org/10.3390/publications 9030028

\section{Academic Editors:}

Belén Puebla-Martínez,

Jorge Gallardo-Camacho,

Carmen Marta-Lazo and Luis

Miguel Romero-Rodríguez

Received: 4 May 2021

Accepted: 29 June 2021

Published: 3 July 2021

Publisher's Note: MDPI stays neutral with regard to jurisdictional claims in published maps and institutional affiliations.

Copyright: (c) 2021 by the authors. Licensee MDPI, Basel, Switzerland. This article is an open access article distributed under the terms and conditions of the Creative Commons Attribution (CC BY) license (https:// creativecommons.org/licenses/by/ $4.0 /)$.

\begin{abstract}
The present study examines a sample of 220 pieces of news related to human evolution, written in Spanish and published over a period of two years, both in digital and print media. The aim of this study is to assess the rigor and coherence of the information in the news in our sample with scientific knowledge on the theory of evolution. To this end, errors and the incorrect use of concepts related to biological evolution are identified, classified according to criteria resulting from the review of previous studies, and finally, the frequency of errors identified in news published in print media is compared with that identified in digital media. The results presented allow us to highlight the significantly high frequency of errors in the news analyzed and the most frequent error categories. Results are discussed within the frame of the important role that scientific journalism plays in the processes of knowledge dissemination, in this case, related to human evolution.
\end{abstract}

Keywords: science education; human evolution; communication media; Spanish media; science communication

\section{Introduction}

The evolutionary theory lies at the core of current biological knowledge and allows us to make sense of biological diversity and its change over time [1]. Unsurprisingly, evolution education is worldwide pointed out as one of the crucial ingredients in the biology curriculum [2]. As a consequence, the examination of how people give meaning to evolutionary concepts is attracting increasing interest in the field of education [3,4], as well as in the area of public understanding of science $[5,6]$.

On a separate but not unrelated issue, the influence that communication media has on shaping public opinion toward science-related issues has been widely recognized [7,8], along with the role that it plays as a source of learning $[9,10]$. This fact has inspired an increasing number of research projects with the objective of examining how mass media covers scientific knowledge on topics such as health [11,12], energy [13,14], technology [15], food and agriculture [16], and climate change [17], to mention just a few relevant examples.

In this context, significant research projects have also emerged to analyze media coverage related to the evolutionary theory, for instance, to examine the accuracy that media affords to evolutionary concepts [18], to study the influence that mass media has on the dissemination of Darwin-skeptic ideas, and to look into the impact that celebrities' claims have on shaping public opinion about evolution [19]. Nonetheless, little attention, if any, has been awarded to the analysis of the journalistic content linked to the issue of human evolution.

In this respect, it should be noted that the notion that the human being is not alien to the evolutionary theory is not a minor matter. On the contrary, it is an essential point of current biological understanding; firstly because it leads us to an in-depth grasp of human's nature, their culture, behavior, and multilevel social organization [20] and secondly because 
current research indicates that a pedagogical emphasis on human examples is an effective procedure to teach essential notions of evolution [21].

In sum, considering together, on the one side, the significance of human evolution for comprehending evolutionary concepts and, on the other side, the crucial role that communication media plays as a driving force for understanding science, it seems certainly relevant to tackle the study of the information appearing in media related to human evolution, particularly due to the lack of previous research.

Accordingly, the present study examines the information that communication media in Spanish disseminated on the particular issue of human evolution over two years (2015-2017). More specifically, the objectives posited for the present research project are as follows:

1. To identify errors and inappropriate usages of scientific concepts linked to the topic of human evolution in the news texts consisted of the sample;

2. To classify the errors identified in accordance with the categories derived from previous research to analyze their prevalence and conclude the influence that these errors may have on the correct understanding of issues related to human evolution by the public;

3. In line with the methodological procedures that previous research employs to examine media information about evolutionary theory $[18,22]$, this study will try to distinguish the pieces of news published in digital media and those published in print media in order to relate the errors detected with their publication source.

Ultimately, the present study seeks to provide evidence for the scientific community to assess the rigor of the news disseminated through the communication media regarding human evolution, which is information that might be useful to improve the processes of dissemination of scientific knowledge in our society.

\section{Materials and Methods}

2.1. Sample

A total of 220 pieces of news published in Spanish in different communication media between 1 December 2015 and 1 December 2017 were analyzed. The pieces of news were collected through the digital periodical library MyNews (https:/ / www.mynews.es accessed on 1 December 2017), which offers press material from a wide range of communication media [23], especially within Spain [24]. In a language that presents so many communication media, the sample size became enormous in a relatively short time. A period that allowed the collection of a significant amount of news was delimited following the example of previous studies [11,18].

This platform "MyNews" is a digital search engine that returns a collection of PDF files in which the informative pieces that fit the search criteria are included. It has been previously used in investigations that conducted content analyses $[25,26]$. The procedure utilized to select the sample was initiated with the search of news by using the following combination of keywords and Boolean operators: evolution AND homo OR human OR man (in Spanish: evolución AND homo OR humano OR hombre). The result of this search yielded 599 pieces of news found in the analysis of 607 printed sources (491 newspapers and 116 magazines) and 795 digital information resources. Afterward, those pieces of news that were unrelated to the topic of human evolution were discarded. Moreover, only the latest release of the news items was included in the sample, when repeated versions of the same information were found. As a consequence, the final sample consisted of 220 pieces of news. Most of the news items came from Spanish media communication (80.9\%). The remaining news pieces were from media in four Latin American countries-Argentina, Mexico, Chile, and Colombia.

The complete list of the pieces of news analyzed in the present study is available in the Supplementary Materials. 


\subsection{Study Variables and Coding Procedure}

Each piece of news in the sample was coded according to the following variables:

(a) Accuracy of the news: nominal variable with two possible values: correct or incorrect. This group includes those pieces of news containing at least one error related to misconceptions associated with scientific knowledge on the theory of evolution;

(b) Number of mistakes per incorrect piece of news: discrete, continuous variable that can have an integer value starting from 1;

(c) Communication medium: nominal variable with two possible values-digital communication media or print media;

(d) Category of conceptual error: qualitative nominal variable referring to the ascription of the errors found in the sample to the categories of improper uses of scientific concepts about human evolution considered in the present study. Table 1 presents a description of each category, together with the most habitual incorrect uses in each category and the references of the studies where these types of conceptual errors are previously cited.

Table 1. Description of the categories of conceptual errors used for the analysis of improper uses of scientific concepts related to the theory of evolution. Together with this, the references of the studies used to substantiate the definition of each category are also indicated in the third column.

\begin{tabular}{cc}
\hline Category & Description \\
\hline Linearity & $\begin{array}{c}\text { Evolution as a one-way process, } \\
\text { developed in one unequivocal sense } \\
\text { toward the development of more evolved } \\
\text { species. }\end{array}$
\end{tabular}

Types of Errors Associated with the Category

References to missing links and evolutionary events circumscribed to very limited geographical contexts [27]. Reference to a radical species extinction with the purpose of giving room to other more modern species [28].

Reference to the existence of more advanced or evolved species.

Reference to supposed benefits, aims, or aspirations guiding evolutionary processes $[29,30]$.

References to an alleged intentionality of biological functions [30,31].

Mention of the existence of a plan, design, or project seeking the best-adapted individuals [32].

Finalist Evolution pursues an ultimate aim or purpose, providing evolutionary changes with intentionality.

References relating evolution with adaptations of specific

individuals within the species, disregarding the concept of population [33].

Evoking individual phenotypical characteristics as if these were inheritable per se, independently from their genetic basis [27].

Statements that suggest that certain phenotypical traits are lost due to lack of use or function [34].

The human being as the end and objective of evolution. Evolutionary

Anthropocentric processes are justified by the sole existence of human beings and present these as the ultimate purpose of evolution.
References to the fact the human beings are the object of evolutionary processes [35].

Arguments that justify the evolutionary changes based on the existence of human beings.

Statements implying that the natural environment and the changes taking place in it are subordinated to and at the service of human beings [36,37].

Taxonomic mistakes when explaining phylogenetic relations of humans with other species, including errors such as describing Homo sapiens as apes and not as hominids. Statements attributing evolutionary capacities to certain organs, such as the brain.

Conceptual errors
Incorrect use of biological concepts and notions with the goal of explaining evolutionary changes.
References to social conducts and habits as inheritable.

Overestimating the role of random processes in biological evolution $[27,28]$. 
Table 1. Cont.

\begin{tabular}{|c|c|c|}
\hline Category & Description & Types of Errors Associated with the Category \\
\hline Human race & $\begin{array}{l}\text { Use of the term race as a synonym of } \\
\text { species and/or with the goal of dividing } \\
\text { human groups on the basis of certain } \\
\text { hereditary characteristics }\end{array}$ & $\begin{array}{l}\text { Explicit mention of the existence of races or subspecies } \\
\text { within the Homo sapiens species [38]. } \\
\text { References to the human race instead of the human genus } \\
\text { [39]. }\end{array}$ \\
\hline Science fiction & $\begin{array}{l}\text { Speculation about future scenarios in } \\
\text { which certain evolutionary changes, } \\
\text { consequences of scientific or technical } \\
\text { development, or human activity in the } \\
\text { environment are considered inexorable. }\end{array}$ & $\begin{array}{c}\text { Statements extrapolating the current knowledge related to } \\
\text { evolutionary processes to future scenarios, often predicting } \\
\text { catastrophes, extinctions, or radical changes in the biological } \\
\text { environment with no scientific evidence [40,41]. } \\
\text { Unreal descriptions of changes in living beings or their } \\
\text { biological environment as a consequence of scientific and } \\
\text { technical development }[42,43] \text {. } \\
\text { Fantasy explanations of future evolutionary processes }\end{array}$ \\
\hline Other errors & $\begin{array}{c}\text { Errors not classifiable within the previous } \\
\text { categories. }\end{array}$ & $\begin{array}{l}\text { Excessive interpretations lacking a theoretical basis or } \\
\text { abusive simplifications [44]. }\end{array}$ \\
\hline
\end{tabular}

\subsection{Analysis Procedure of the Pieces of News}

The pieces of news in the sample were examined according to the variables mentioned above. To this end, the seven categories of conceptual errors presented in Table 1 were first established using a bibliographical revision. The investigations that were followed to develop the set of categories are those cited in the third column of Table 1. Later, two members of the research team (a doctor in Zoology and a teacher with a specialization in science education) jointly classified $20 \%$ of the pieces of news in the sample.

Then, both researchers completed the error classification of the remaining pieces of news in the sample independently, and finally, the level of agreement between the resulting classifications was analyzed. It is worth noting that in relation to the cases where various errors belonging to the same category were identified in the same piece of news, these counted as one per category.

\subsection{Statistical Procedures}

The study of the level of concordance between the two researchers who assessed the errors detected in the pieces of news that make up the sample was carried out using Cohen's kappa coefficient [45]. Furthermore, the differences between nominal variables were tested using the Chi-square test, estimating the effect size by Cramer's V [46,47]. The level of significance considered in the study is 0.05 , and statistical procedures were carried out using a spreadsheet.

\section{Results}

The results of the present research project are presented below in two sections. In one section, the analysis of errors detected for the whole sample, with a detail of the frequencies for each of the seven error categories considered in this study is presented. In the other section, the study of the proportion of pieces of news with errors, together with the possible relationship existing between the frequency of pieces of news with errors and the type of communication medium, is shown.

\subsection{Review of Errors Found in the Entire Set of News Pieces in the Sample}

A total of 448 incorrect uses of scientific concepts related to the evolution of human beings were found in all 220 pieces of news comprising the sample analyzed. Table 2 presents an overview of illustrative examples found in the pieces of news for each one of all seven error categories, together with the relative frequency of each category, compared to the total errors, and the level of concordance between the two reviewers (Cohen's kappa coefficient). 
Table 2. Illustrative cases of errors corresponding to each category, along with the relative frequency of cases classified in the error categories $(n=448)$. The last column shows the level of agreement between the two reviewers of the pieces of news (Cohen's kappa).

Category
"In this way, Piltdown, and transitively the island, was transformed into the cradle of
humankind" [48].
"The human being went from being a vulgar ape to dominating the rest of the natural
world. On its way to the summit of the Universe, it invented gods, nations and limited
companies." [49].
"They had descended from walking apes, who eventually evolved into more advanced
human beings" [50].

"It does not add up for such primitive beings: this behaviour is supposed to be restricted to more advanced species, such as modern humans and Neanderthals" [54].

Anthropocentric "This circumstance would imply an important challenge for homo sapiens, who would

"Humans are not so exposed to natural selection anymore, but this is an anomaly in the species' story." [52].

“20.000 years ago there were five species of hominids on the planet; today there is one, Homo sapiens." [56].

"We are almost the same as the Cro-Magnon and Homo sapiens, genetically there is no difference" [57].

"Indeed, evolution had until now been random" [58].

Conceptual errors "Evolution depends on two fundamental aspects: mutations in the genes and

environmental changes. Human beings will continue to experience mutations and most of these will make individuals non-viable", the scientist asserts." [59]

"Cavemen beat their own kind to death, as much as great apes did, therefore it is very

likely that we have inherited this violent conduct from our common ancestors throughout evolution." [60]

"The Ramapithecus, who became extinct about 8 million years ago, but left the genetic seed of our current human races." [61]

Race "Greed and ambition are represented in the creation of global empires with white man predominating as the superior race." [62]

"This illustration of the evolutionary stages from primate to Homo sapiens appears from it, therefore a black man is little more than a macaque." [63]

"In the same way that the triumph of Homo sapiens entailed the extinction of

Neanderthals, the success of Robo sapiens will mean an evolutionary leap and will make the current human being obsolete." [52]

Science fiction "...like with the creation of machine-men: hybrids that will give way to Homo sapiens 2.0 in the perspective of replacing man for a robot." [48]

"Scientific and technological advances have allowed humans to escape the effects of natural selection." [64]

"Smartphones make us millions of times more intelligent than humans of just 20 years

Other errors ago." [65]

"Scientists can quickly, cheaply and surprisingly precisely fix nature's grammatical errors." [66]

\subsection{Review of the News Comprised in the Sample}

With regard to the analysis of the proportion of news with concept misuses, $79.1 \%$ $(n=174)$ of pieces of news composing our sample presented at least one conceptual error in discussing notions linked to the evolution of human beings. Among these pieces of 
news with errors, $51.7 \%(n=90)$ had two or three errors, and $24.1 \%(n=42)$ presented four errors or more. None of the pieces of news analyzed presented more than six errors.

Besides that, $67.7 \%$ of the entire 220 pieces of news were published in digital media and $32.3 \%$ in print media (newspapers and magazines). Among the pieces of news published in digital media, $77.2 \%(n=115)$ had at least one information error and presented 2.6 errors per piece of news on average. In the case of print media news, at least one error was found in $83.1 \%$ of them, and the average was 2.5 errors per piece of news. The differences between digital and print media regarding the presence of incorrect pieces of news were not significant $\left(\chi^{2}=(4, n=220 ; p<0.1)=1.12\right)$, and the effect size of the comparison indicated a weak association between variables $(\mathrm{V}$ de Cramer $=0.07)$.

\section{Discussion and Conclusions}

The media have an essential educational role [10,67], especially in the field of science, since once formal education is completed, the public acquires new scientific knowledge mainly through the media $[68,69]$. Therefore, to fight the spread of scientific misinformation, rigorous content must be shared with the public [70]. As a consequence, studying the rigor of communication media in disseminating scientific knowledge is a matter of undeniable social relevance $[11,18,71]$. In this sense, research studies have been carried out aimed at analyzing the properness of information disseminated by communication media with scientific knowledge [72] in matters such as climate change [17], energy [13,14], and food and agriculture [16]. However, research examining the rigor of journalistic dissemination of scientific knowledge with regard to human evolution happens to be much less frequent, in spite of the influence that the media news may have on this area of knowledge in particular.

In this context, the present research studies information published in 220 pieces of news in digital and print communication media in Spanish, between the end of 2015 and the end of 2017 about biological evolution, with the aim of assessing the level of consistency with scientific knowledge.

The evidence presented is structured around three aspects: error frequency in the pieces of news, the categories of errors found, and the relationship between these and the type of medium.

With regard to the first aspect, almost 8 out of 10 pieces of news analyzed showed at least one error in the information they disseminate on human evolution, and among these, three out of four presented two or more errors. The significant prevalence of errors in the news examined is consistent with the persistence of errors linked to the comprehension of evolutionary processes [27], on the one hand, and, on the other, with the significantly high rate of confusion or inaccuracies that can be found in the information that media spread about scientific and technical matters [73].

With regard to the types of errors observed in the pieces of news analyzed, the most frequent happened to be either those referring to the supposed intentionality or purpose of evolution (finalist category), or those making a mistaken use of biological concepts with the aim of explaining evolutionary changes (category of conceptual errors). This tendency is consistent with the results presented by previous research analyzing the presence of finalist-type understandings related to the evolutionary processes [29] and also with studies examining conceptual errors related to the theory of evolution [28].

Moreover, almost 2 out of 10 errors presented assertions that induce readers to think that human beings are the ultimate end of evolution (category of anthropocentric errors), which is a fact that concurs with previous studies revealing a tendency to give human characteristics and even shape to natural processes during initial stages of comprehension [74].

Mistaken expressions suggesting that evolution is a one-way process toward the development of more perfect species appeared with a similar frequency (errors included in the category linearity). This frequency is similar in previous studies [27,34].

The errors linked to fictitious scenarios as in consonance with scientific evidence on the evolution of humankind (category Science fiction) showed a lower prevalence than the previous categories, but were still relevant, as they implied slightly over 1 out of 
10 errors found in the sample. Previous studies also indicate an increasing tendency in the appearance of these types of contents, precisely for their simplicity and for being effectively suggestive [42,75].

With regard to the frequency of errors related to the use of the concept of race, it was certainly lower than the frequency for other categories. However, the qualitative importance that this type of error represents cannot go unmentioned [76,77], nor can the gravity of the errors in some of the evidence found in the sample. Thus, it is relevant to underline the role that communication media should play in avoiding the propagation of conceptual errors, such as using the term "race" to refer to phenotypical variations in the human being that can contribute to the persistence of beliefs with no scientific basis but with important social-type implications.

Finally, regarding the differences found among media, the percentage of correct pieces of news were higher in the case of digital media, compared to print media (22.8\% compared to $16.9 \%$ ), and the frequency of pieces of news with only one mistake was lower in digital platforms ( $16.8 \%$ in digital media, compared to $24 \%$ in print media). These differences, however, did not seem to be significant in the sample analyzed, which reinforces the idea that there is uniformity among the contents of both types of media. These observations seem to be in line with the case made in previous studies, in the sense that digital news has its origin in the traditional print press news [78].

To sum up, this set of evidence indicates that the pieces of news analyzed have ample room for improvement regarding the information they communicate about evolutionary processes related to human beings. However, the need to complete the observations in this study with new research that can confirm or disprove the tendencies observed in this research project cannot go unmentioned. To accomplish this task, research studies should be carried out with samples from different contexts, including different language and cultural contexts, a line of research that can help avoid impaired quality in the research disseminated by scientific journalism $[79,80]$. In addition, this paper omits the analysis of the connection between the journalistic genres and the occurrence of conceptual errors in the news about human evolution, which is an issue that further research should ponder for its examination.

Supplementary Materials: The following are available online at https:/ /www.mdpi.com/article/10 $.3390 /$ publications $9030028 / \mathrm{s} 1$.

Author Contributions: Conceptualization, J.D.V.; methodology, J.D.V.; software, J.D.V.; validation, J.D.V., A.A., J.A.G., and J.D.V.; investigation, J.D.V., A.A., and J.A.G.; resources, A.A.; data curation, J.D.V., A.A., and J.A.G.; writing—original draft preparation, J.D.V.; writing—review and editing, J.D.V.; visualization, A.A.; supervision, J.D.V.; project administration, J.D.V.; funding acquisition, A.A. All authors have read and agreed to the published version of the manuscript.

Funding: This research was funded by the University of the Basque Country through the project PES20/49.

Data Availability Statement: Data are available on request from the authors.

Conflicts of Interest: The authors declare no conflict of interest.

\section{References}

1. Teixeira, P. Acceptance of the theory of evolution by high school students in Rio de Janeiro, Brazil: Scientific aspects of evolution and the biblical narrative. Int. J. Sci. Educ. 2019, 41, 546-566. [CrossRef]

2. Deniz, H.; Borgerding, L.A. Evolution Education around the Globe; Springer: Berlin/Heidelberg, Germany, 2018.

3. Alanazi, F.H. The Perceptions of Students in Secondary School in Regard to Evolution-Based Teaching: Acceptance and Evolution Learning Experiences-The Kingdom of Saudi Arabia. Res. Sci. Educ. 2019, 1-29.

4. Fančovičová, J. The Transformation of Scientific Knowledge Concerning Evolution into the Content of the Curriculum and its Potential to Create a Conceptual Change in the Conceptual Structures of Pupils. EURASIA J. Math. Sci. Technol. Educ. 2019, 15, em1759. [CrossRef]

5. Cook, C.N.; Sgrò, C.M. Poor understanding of evolutionary theory is a barrier to effective conservation management. Conserv. Lett. 2019, 12, e12619. [CrossRef] 
6. McCain, K.; Kampourakis, K. Which question do polls about evolution and belief really ask, and why does it matter? Public Underst. Sci. 2018, 27, 2-10. [CrossRef] [PubMed]

7. Lewis, A.; Lord, A.S.; Czeisler, B.M.; Caplan, A. Public education and misinformation on brain death in mainstream media. Clin. Transplant. 2016, 30, 1082-1089. [CrossRef] [PubMed]

8. Metag, J.; Füchslin, T.; Schäfer, M.S. Global warming's five Germanys: A typology of Germans' views on climate change and patterns of media use and information. Public Underst. Sci. 2017, 26, 434-451. [CrossRef]

9. Storksdieck, M. Critical information literacy as core skill for lifelong STEM learning in the 21st century: Reflections on the desirability and feasibility for widespread science media education. Cult. Stud. Sci. Educ. 2016, 11, 167-182. [CrossRef]

10. McCombs, M.; Valenzuela, S. Setting the Agenda: Mass Media and Public Opinion; John Wiley \& Sons: Hoboken, NJ, USA, 2020.

11. Miyawaki, R.; Shibata, A.; Ishii, K.; Oka, K. News coverage of cancer in Japanese newspapers: A content analysis. Health Commun. 2017, 32, 420-426. [CrossRef]

12. Orr, D.; Baram-Tsabari, A. Science and Politics in the Polio Vaccination Debate on Facebook: A Mixed-Methods Approach to Public Engagement in a Science-Based Dialogue. J. Microbiol. Biol. Educ. 2018, 19. [CrossRef]

13. Biddinika, M.K.; Syamsiro, M.; Novianti, S.; Nakhshiniev, B.; Aziz, M.; Takahashi, F. Dissemination of technology information through YouTube: A case of renewable energy technology. Telkomnika 2019, 17, 1526-1538. [CrossRef]

14. De Filippo, D.; Serrano-López, A.E. From academia to citizenry. Study of the flow of scientific information from projects to scientific journals and social media in the field of "Energy saving". J. Clean. Prod. 2018, 199, 248-256. [CrossRef]

15. Mejía, C.; Kajikawa, Y. Technology news and their linkage to production of knowledge in robotics research. Technol. Forecast. Soc. Chang. 2019, 143, 114-124. [CrossRef]

16. McCluskey, J.; Squicciarini, M.P.; Swinnen, J. Information, Communication, and Agricultural and Food Policies in an Age of Commercial Mass and Social Media. Glob. Chall. Future Food Agric. Policies 2019, 1, 351.

17. Ma, S.; Kirilenko, A.P. Climate change and tourism in English-language newspaper publications. J. Travel Res. 2020, 59, 352-366. [CrossRef]

18. Bohlin, G.; Höst, G.E. Evolutionary explanations for antibiotic resistance in daily press, online websites and biology textbooks in Sweden. Int. J. Sci. Educ. Part B 2015, 5, 319-338. [CrossRef]

19. Arnocky, S.; Bozek, E.; Dufort, C.; Rybka, S.; Hebert, R. Celebrity opinion influences public acceptance of human evolution. Evol. Psychol. 2018, 16, 1474704918800656. [CrossRef] [PubMed]

20. Jantsch, E. The Evolutionary Vision: Toward a Unifying Paradigm of Physical, Biological and Sociocultural Evolution; Routledge: New York, NY, USA, 2019.

21. Pobiner, B.; Watson, W.A.; Beardsley, P.M.; Bertka, C.M. Using Human Examples to Teach Evolution to High School Students: Increasing Understanding and Decreasing Cognitive Biases and Misconceptions; Evolution Education Re-considered; Springer: Berlin/Heidelberg, Germany, 2019; pp. 185-205.

22. Peat, M.; Fernandez, A. The role of information technology in biology education: An Australian perspective. J. Biol. Educ. 2000, 34, 69-73. [CrossRef]

23. Repiso, R.; Rodríguez-Pinto, M.; García-García, F. Posicionamiento y agrupación de la prensa española: Análisis de contenido de las noticias generadas en la Jornada Mundial de la Juventud 2011. Estud. Sobre Mensaje Periodís. 2013, 19, 1091-1106. [CrossRef]

24. Grau, J.; Guallar, J. My News, la hemeroteca digital de la prensa española. Prof. Inf. 2004, 13, 466-476.

25. Repiso, R.; Merino-Arribas, A.; Chaparro-Domínguez, M.Á. Agrupación de las universidades españolas en la prensa impresa nacional. Rev. Esp. Doc. Cient. 2016, 39, 131. [CrossRef]

26. Rodari, P.; Mathieu, A.; Xanthoudaki, M. The Professionalisation of the Explainer: A European Perspective. In Proceedings of the CST International Public Communication of Science and Technology Conference, Florence, Italy, 18-20 April 2012 ; pp. 249-266.

27. Gregory, T.R. Understanding natural selection: Essential concepts and common misconceptions. Evol. Educ. Outreach 2009, 2, 156-175. [CrossRef]

28. Isaak, M. Five Major Misconceptions about Evolution. The TalkOrigins Archive: Exploring the Creation/Evolution Controversy. 2003. Available online: http://www.talkorigins.org/faqs/faq-misconceptions.html\# (accessed on 1 December 2017).

29. Heredia, S.C.; Furtak, E.M.; Morrison, D. Exploring the influence of plant and animal item contexts on student response patterns to natural selection multiple choice items. Evol. Educ. Outreach 2016, 9, 1-11. [CrossRef]

30. Marrero-Delgado, G.A. Estudio de Caso de las Concepciones de Estudiantes Universitarios Sobre Mutación, Selección Natural y Adaptación; Universidad de Puerto Rico: San Juan, PR, USA, 2017.

31. Grau, R.; De Manuel, J. Enseñar y aprender evolución: Una apasionante carrera de obstáculos. Alambique 2002, $32,56-64$.

32. De la Gándara Gómez, M.; Quílez, M.J.G. El aprendizaje de la adaptación. Alambique Didact. Cienc. Exp. 2002, 32, 65-72.

33. Nowak, M.A. Evolutionary Dynamics: Exploring the Equations of Life; Harvard University Press: London, UK, 2006.

34. Morales Ramos, E.M. Concepciones y Concepciones Alternativas de Estudiantes Universitarios/as de Biologia y Futuros Maestros/as de Ciencia de Escuela Secundaria sobre la Teoria de Evolucion Biologica por Seleccion Natural. Ph.D.Thesis, University of Puerto Rico, San Juan, PR, USA, 2016.

35. Disinger, J.F.; Tomsen, J.L. Environmental education research news. Environmentalist 1995, 15, 3-9. [CrossRef]

36. Clayton, S. New ways of thinking about environmentalism: Models of justice in the environmental debate. J. Soc. Iss. 2000, 56, 459-474. [CrossRef] 
37. Kahriman-Ozturk, D.; Olgan, R.; Tuncer, G. A qualitative study on Turkish preschool children's environmental attitudes through ecocentrism and anthropocentrism. Int. J. Sci. Educ. 2012, 34, 629-650. [CrossRef]

38. Templeton, A.R. Human races: A genetic and evolutionary perspective. Am. Anthropol. 1998, 100, 632-650. [CrossRef]

39. McDonald, B. The reproduction of biological 'race'through physical education textbooks and curriculum. Eur. Phys. Educ. Rev. 2013, 19, 183-198. [CrossRef]

40. Alonso, A.; Galán, C. La Tecnociencia y su Divulgación: Un Enfoque Transdisciplinar; Anthropos Editorial: Barcelona, Spain, 2004; Volume 15.

41. Petit, M.F.; Solbes, J. El cine de ciencia ficción en las clases de ciencias de enseñanza secundaria (II). Análisis de películas. Rev. Eureka Sobre Enseñ. Divulg. Cienc. 2016, 13, 176-191. [CrossRef]

42. Alcíbar, M. La divulgación mediática de la ciencia y la tecnología como recontextualización discursiva. Anal. Quad. Comun. Cult. 2004, 31, 43-70.

43. Moreno Muñoz, M.; Ibáñez, P.E. Elementos Para la Resolución de Controversias en el Debate Sobre Biotecnología y Sociedad; Rodríguez Alcázar, F.J., Medina Doménech, R.M., Sánchez Cazorla, J.A., Eds.; Ciencia, tecnología y Sociedad: Contribuciones para una Cultura de la paz; Universidad de Granada: Granada, Spain, 1997; pp. 289-314.

44. Ladle, R.J.; Jepson, P.; Whittaker, R.J. Scientists and the media: The struggle for legitimacy in climate change and conservation science. Interdiscip. Sci. Rev. 2005, 30, 231-240. [CrossRef]

45. Viera, A.J.; Garrett, J.M. Understanding interobserver agreement: The kappa statistic. Fam. Med. 2005, 37, 360-363.

46. Kline, R.B. Beyond Significance Testing: Reforming Data Analysis Methods in Behavioral Research; APA: Washington, DC, USA, 2004.

47. Villanueva, X. El aprendizaje de las plantas como seres vivos: Una metodología basada en el dibujo infantil. Ikastorratza Rev. Didact. 2017, 18, 106-123. [CrossRef]

48. Barbería, J. Carlos López Otín: “La Ciencia Revela la Verdadera Belleza del Mundo". Available online: https:/ / elpais.com/ elpais/2016/12/21/eps/1482275152_148227.html (accessed on 3 May 2021).

49. Pilar, S. 'Homo Deus': El largo Camino del ser Humano Hasta Alcanzar la Divinidad. Available online: http:/ / www.rtve.es / noticias/20161017/homo-deus-largo-camino-del-ser-humano-hasta-alcanzar-divinidad/1426660.shtml (accessed on 3 May 2021).

50. Omnia. El Fósil que Cambió Todo. Available online: https://vanguardia.com.mx/articulo/el-fosil-que-cambio-todo (accessed on 3 May 2021).

51. Velasco, E. La Humanidad Comenzó con la Cocina.La Vanguardia. Available online: http://www.lavanguardia.com/ciencia/ quien/20170307 /42603941907/humanidad-comenzo-cocina-ferran-adria-eudald (accessed on 3 May 2021).

52. Mediavilla, D. La Especie que Quiere Acabar con la Evolución. Available online: https://elpais.com/elpais/2017/11/08/ciencia/ 1510168469_737727.html (accessed on 3 May 2021).

53. Publicitario Farmaceutico, La Salud Dental del Hombre Primitivo era Mucho Mejor que la del Actual. Available online: https: / / www.consejosdetufarmaceutico.com/belleza/bucodental/la-salud-dental-del-hombre-prehistorico-mejor-que-la-actual/ (accessed on 3 May 2021).

54. Yanes, J. Los Humanos no Estábamos Solos en África. Available online: http://blogs.20minutos.es/ciencias-mixtas/2017/05/13 /los-humanos-no-estabamos-solos-en-africa/ (accessed on 3 May 2021).

55. Villahizán, J. Una nueva revolución. Available online: https://www.diariodeburgos.es/ (accessed on 3 December 2018).

56. Rodríguez, B. En Centenares de años Habrá Humanos Genéticamente Iguales a Seres de Plástico. Available online: http: / / www.eldiario.es/tenerifeahora/sociedad/centenares-humanos-geneticamente-metalicos-plastico_0_569743140 (accessed on 3 May 2021).

57. La Provincia. Lo Mejor de la Ciencia Española en. 2016. Available online: http://www.laprovincia.es/sociedad/2016/12/31 / mejor-ciencia-espanola-2016/895434.html. (accessed on 3 May 2021).

58. Quijada, P. Eudald Carbonell: «Los Humanos que Nazcan en Marte Originarán una Nueva Especie». Available online: http: //www.abc.es/ciencia/abci-eudald-carbonell-nuestra-especie-tiene-decidir-hacia-donde-quiere-201702022053_noticia.html (accessed on 3 May 2021).

59. Chaparro, L. Nuestra Especie, al Ritmo de la Evolución. Available online: http://www.heraldo.es/noticias/suplementos/tercermilenio/investigacion/2017/11/07/nuestra-especie-ritmo-evolucion-1206200-2121029.html (accessed on 3 May 2021).

60. De Jorge, J. Caín está en Nuestras Raíces. ABC 2016. p. 44. Available online: https:/ /www.abc.es/ciencia/abci-templo-masantiguo-humanidad-rendia-culto-craneo-201706282204_noticia.html (accessed on 3 November 2017).

61. Kaosenlared Chile y el Mundo. Crónica de Ruperto Concha Pensamiento Sensorial. Available online: http://kaosenlared.net/ chile-y-el-mundo-cronica-de-ruperto-concha-pensamiento-sensorial/ (accessed on 3 May 2021).

62. Cortés, C. De Animales a Dioses. El Informador. Available online: http://opinion.informador.com.mx/Columnas/2017/08/23 /de-animales-a-dioses/ (accessed on 3 May 2021).

63. Guaycochea de Onofri, R. Del Perito Moreno a la Colonia en Marte. Los Andes. Available online: http:/ /www.losandes.com.ar/ article/del-perito-moreno-a-la-colonia-en-marte (accessed on 3 May 2021).

64. Soto, Á. Los Rusos no Quieren una Tercera Revolución en cien años. Available online: http:/ / www.diariovasco.com/culturas / libros/201702/28/rusos-quieren-tercerarevolucion-20170227220610-rc.html (accessed on 3 May 2021).

65. Zunni, J.L. Inteligencia Artificial vs. Liderazgo Real. Available online: https://www.media-tics.com/noticia/7348/management/ inteligencia-artificial-vs.-liderazgo-real.html (accessed on 3 May 2021). 
66. Kusko, F. La Edición de la vida. el Inquietante Poder de "Reescribir" los Genes. Available online: https://www.lanacion.com.ar/ 2060732-la-edicion-de-la-vida-el-inquietante-poder-de-reescribir-los-genes (accessed on 3 May 2021).

67. Masterman, L. La Enseñanza de los Medios de Comunicación; Ediciones de la Torre: Madrid, Spain, 2010.

68. Boykoff, M.T.; Yulsman, T. Political economy, media, and climate change: Sinews of modern life. Wiley Interdiscip. Rev. Clim. Chang. 2013, 4, 359-371. [CrossRef]

69. Dunwoody, S. Science Journalism: Prospects in the Digital Age; Bucchi, M., Trench, B., Eds.; Routledge Handbook of Public Communication of Science and Technology; Routledge: New York, NY, USA, 2021; pp. 15-26.

70. Barnett, P.J.; Kaufman, J.C.; Patmore, C. 22 Truth Shall Prevail; Kaufman, B., Kaufman, J.C., Eds.; Pseudoscience: The conspiracy Against Science; Mit Press: Cambridge, UK, 2018; pp. 562-576.

71. García Carmona, A. Naturaleza de la ciencia en noticias científicas de la prensa: Análisis del contenido y potencialidades didácticas. Ensen. Cienc. Rev. Investig. Exp. Didact. 2014, 32, 493-509. [CrossRef]

72. Hayes, R.; Grossman, D. A Scientist's Guide to Talking with the Media: Practical Advice from the Union of Concerned Scientists; Rutgers University Press: New Brunswick, NJ, USA, 2006.

73. Porlezza, C.; Maier, S.R.; Russ-Mohl, S. News accuracy in Switzerland and Italy: A transatlantic comparison with the US press. Journal. Pract. 2012, 6, 530-546. [CrossRef]

74. Villarroel, J.D.; Villanueva, X. A study regarding the representation of the sun in young children's spontaneous drawings. Soc. Sci. 2017, 6, 95. [CrossRef]

75. Barceló, M. Ciencia y ciencia ficción. Quark 2003, 6, 97-101.

76. McChesney, K.Y. Teaching diversity: The science you need to know to explain why race is not biological. SAGE Open 2015, 5, 2158244015611712. [CrossRef]

77. Rufo, F.; Capocasa, M.; Marcari, V.; D’arcangelo, E.; Danubio, M.E. Knowledge of evolution and human diversity: A study among high school students of Rome, Italy. Evol. Educ. Outreach 2013, 6, 1-10. [CrossRef]

78. González, M.A. La comunicación científica en la prensa digital española: Radiografía de sus fuentes informativas. Commun. Pap. 2018, 7, 55-80. [CrossRef]

79. Bereziartua, G.; Boillos, M.M. Laburpen zientifikoen izaera diskurtsiboa: Ikastorratza aldizkariaren azterketa. Ikastorratza Rev. Didact. 2020, 25, 179-207. [CrossRef]

80. Meyer, P. The Vanishing Newspaper: Saving Journalism in the Information Age; University of Missouri Press: Columbia, MO, USA, 2009. 